\title{
NEW SPATIAL PLANNING DATA ACCESS METHODS THROUGH THE IMPLEMENTATION OF THE INSPIRE DIRECTIVE ${ }^{1}$
}

\author{
Iwona Kaczmarek, M.Sc. \\ Faculty of Environmental Engineering and Geodesy \\ Wroctaw University of Environmental and Life Sciences \\ e-mail:iwona.kaczmarek@up.wroc.pl
}

\author{
Adam Iwaniak, PhD \\ Faculty of Environmental Engineering and Geodesy \\ Wroctaw University of Environmental and Life Sciences \\ e-mail:adam.iwaniak@up.wroc.pl \\ Jaromar Łukowicz, M.Sc. \\ Faculty of Environmental Engineering and Geodesy \\ Wroctaw University of Environmental and Life Sciences \\ e-mail: jlukowicz@gmail.com
}

\begin{abstract}
Constant access to reliable information concerning future land use is of utmost importance for the real estate market as well as for spatial monitoring and public participation in spatial planning. The implementation of the INSPIRE Directive (Directive 2007/2/EC of the European Parliament and of the Council of 14 March 2007 establishing an Infrastructure for Spatial Information in the European Community) introduces new means for sharing spatial planning data. According to the Act of March 4 2010 on Spatial Information Infrastructure, which is a transposition of the Directive, every member state is obliged to publish data and metadata concerning the subject of spatial planning. In the Directive, this is defined as a "territory characterized according to its current and future planned functional dimension or socio-economic purpose (e.g., residential, industrial, commercial, agricultural, forestry, recreational)".

In the article, the authors present new possibilities for spatial planning data access, which result from the implementation of the INSPIRE Directive with the use of new information technologies, in the context of real estate management conditions.
\end{abstract}

Keywords: land management, INSPIRE, spatial development plan.

JEL Classification: R00, R52, R58.

Citation: Kaczmarek I., Iwaniak A., Łukowicz J., 2014, New spatial planning data access methods through the implementation of the INSPIRE Directive, Real Estate Management and Valuation, vol. 22, no. 1, pp. $12-24$.

DOI: 10.2478/remav-2014-0002.

\section{Introduction}

Spatial planning is a key instrument in land management, purposefully keeping in mind the principle

\footnotetext{
1 The article was written as part of a project financed by the National Center of Science, granted by decision no.
} DEC-2011/03/N/HS4/03819. 
of sustainable development. The planning process integrates the problems of the state of the environment, land use, and the economic conditions of spatial development. It is a multistage and multilevel process, encapsulating the processes of development management on national, regional and local levels. A municipality has the greatest power in this matter because it holds so-called planning rights, which gives it the competences to create local law and thus, determine land use.

The main role of the spatial development plan (zoning plan) is to determine the future land use of a given area, the principles of spatial development and the location of public investments. The zoning plan also determines a number of additional elements, including the regulations for the transport system, the technical infrastructure, and environmental considerations. According to article 2 of the Spatial Planning and Land Development Act of 27 March 2003, spatial order is "space shaped in a way which creates a harmonious whole and incorporates all the functional, social, economic, environmental, cultural, compositional and aesthetic conditions and requirements, organized in relations".

The Act has a significant impact on the value of real estate which is located within the regulated area. This can be considered in several aspects:

1) How the owner can use the property from the moment the plan comes into force. Article 6, point 1 of the Spatial Planning and Land Development Act states that, "the arrangements in the plan along with other regulations shape the measures in which the owner exercises his or her real property ownership rights." That is why the owner can achieve substantial and insubstantial gain, and the real property can be characterized by its attractiveness on the market depending on the zoning plan, i.e., the permitted land use. What is more, the zoning plan may allow for the temporary continuation of the present land use up to the moment the final development plan is achieved (article 35) or impose a procedure and due date for temporary use and development (article 15, point 11) (SZWAJDLER, 2004).

2) Transport access of a real property, which affects the attractiveness of the property in conjunction with the planned development.

3) Technical infrastructure service, including utilities which will be available in the future - this is important for future investments and concerns functional restrictions as well as cost.

4) The value of the real property. The impact of the plan is not only direct, i.e., it does not only contain regulations which refer to the value directly. It may also have an indirect influence since, when declaring the development of a given area and management regulations within the direct and further proximity of the property in question, it affects what can be referred to as the quality of the area, which is closely related to the idea of spatial order. The development context is of major influence on the value of the property - it is the quality of the area which decides whether it is considered "prestigious", accounted for in the "top" locations, or treated as unattractive for certain uses.

Article 6, point 2 says that "Everyone has the right, lawfully constricted by the bill, to: first of all - "to the development of the area to which they are legally entitled, according to the regulations contained in the local development plan or decisions concerning the terms of use and development of the area", and also "to the protection of their legal interest in the development of areas owned by other people or organizations."

The consequences of creating a zoning plan may include restrictions in current property use or changes in its value. This may result in losses for the owners or long-term users, including material losses in the case of decreasing property value. On the other hand, there is the possibility of gain for the owner if the plan results in an increase in property value. The Spatial Planning and Land Development Act describes both of these situations in article 36: in the case of losses or a decrease in value, the owner or long-term user has the right to pursue a claim or to purchase the property. However, in the case of an increase in property value and the property being sold in a given time frame, the municipality is entitled to charge the owner with the amount of money accounted for in the plan (the so-called zoning fee). The increase in property value caused by a local plan being introduced may happen, e.g., when the regulations in the new plan or the change in the plan allow for industrial or residential use of an area where it had previously been prohibited. That is why zoning plans, being such an important source of information about the possible property use, play a key role both for property owners/users, as well as potential investors.

Śmietana (2012) highlights the significance of information barriers as a factor which restricts the 
efficiency of decision-making processes on the real estate market. Access to information is one of the elements which constitute such a barrier. The authors analyze the results of the survey: "Information barriers for the development of the real estate market. Poland compared to selected countries. STAGE II OF RESEARCH", which shows that information from planning documents, along with land and mortgage registers and the register of historic monuments, constitute a primary source of data about real property and its use.

\section{Methods for publishing spatial planning data}

Zoning plans constitute public and official information, which has to be made available to all interested parties. Methods for publishing plans are closely related to the form in which they have been prepared. The graphical part of the plan may be compiled in several ways and take the following forms:

I. The analog form, in which a drawing of the plan is made on paper.

II. A vector format created using a graphical program, e.g., Corel Draw or a CAD program (e.g., Microstation or Autocad), in a local coordinate system.

III. A vector format created using CAD software which keeps the appropriate topological relations between objects, and incorporates an unambiguous spatial coordinate system.

IV. An object-oriented format using GIS software.

In the former three cases, it is the user who has to interpret the plan. The user has to analyze the planning decision along with the drawing. The processing and usage of the plan in such a form by information systems is considerably limited. Computer techniques, in this case, can only be used to edit the graphics of the drawing of the plan. Additionally, preparing the plan in forms specified in points I and II often generates inaccuracy and inconsistency with the reference data on which the drawing of the plan is based. The third form allows for the planning data to be precisely in accordance with the reference data and also for surveying acreage and length. Using the GIS technology (the fourth form) gives considerably broader possibilities. It allows spatial objects defined in spatial development plans to be gathered, processed, analyzed and published, as well as facilitating their integration with other data collected in the resources of the public administration unit.

Methods for publishing spatial development plans differ not only in terms of how they can be edited. Apart from the employed technologies, important factors also include the size of the municipality, the level of its information infrastructure, financial effort, and the need for information management functionality.

At the moment, the following methods for publishing zoning plans can be observed in Poland:

1) Publishing the act in the format of a PDF file and a raster graphic without spatial reference. This is the most common form of publishing plans on Internet sites of governmental institutions and in official voivodeship journals in the form described above in points I and II.

2) Publication of zoning plans on county and municipality geoportals as raster graphics. The drawing of the plan is georeferenced according to the coordinate system defined in the geoportal, which allows the plan to be located. Such a form is used most often for forms I, II and III.

3) Publication of zoning plans on county and municipality geoportals in the form of vector graphics. Data is unambiguously localized so it can be compared to reference data. This method is most often used in cases III and IV.

4) Publication of zoning plans on county and municipality geoportals in an object-oriented form. Every object has a unique identifier which allows additional information contained in its descriptive attributes to be accessed. On some geoportals, it is possible to perform spatial analysis, e.g., searching for residential areas located on parcels belonging to the State Treasury. Such forms can only be used in case IV.

5) Publication of scanned zoning plans using the WMS service. This is most often used in cases I, II and III.

6) Publication of zoning plans in vector form using the WMS service. This form is most often used in cases III and IV.

7) Publication of zoning plans in object-oriented form using the WFS service. This can only be done in case IV.

It is worth noting that the WMS (Web Map Service) is the simplest form of spatial data sharing compliant with OGC/ISO standards and INSPIRE requirements. This service allows us to acquire a 
map of a given area in raster form (getMap service request), a set of metadata containing some information about the possibilities of use (getCapabilities request), as well as descriptive information about the selected object (getFeatureInfo request). The usage of this publishing format would undoubtedly result in great progress as far as informing citizens about the planning situation within a given municipality is concerned.

The WMS service is an intelligent solution, which constitutes a compromise between performance and information content. The service allows clients to request specific resources using HTTP calls (GET, POST). The service interface uses GET and POST requests with API which is standardized by OGC. WMS uses raster and vector spatial resources as source data. The data received by the user are in raster (png, jpg, gif) or vector (SVG) form. These data are not available in the form of objects, but in the form of images for the purpose of presentation. WMS provides the desired styling and mutual spatial reference. With this form of sharing spatial data, they can be viewed using standard tools (browsers) or simple web and desktop GIS applications. There is no need for specialized graphics rendering tools as is the case for the GML format. Access to the map image is realized by the WMS getMap operation.

However, WMS is not limited to sharing images. When the source data are object-oriented, it is possible to obtain information about the presented objects. This is achieved by the GetFeatureInfo operation. WMS service quality depends on the format and quality of the source data. WMS service can utilize both: raster data, such as scanned plan drawings, and vector data, stored in files and relational or object-oriented databases. Portrayal is understood as assigning the appropriate symbols and styles of published objects, and as the conversion to raster form of objects from a selected area. SLD, used for the purpose of styling, is an XML-like language also standarized by OGC (E. Wozniak, A. Iwaniak, P. Netzel, 2011). When object spatial data are used as a data source, the WMS service can interpret the events generated by the user as a request to provide descriptive information about the indicated objects. Such events are transmitted to the WMS service by the getFeatureInfo operation.

The OGC service interface uses HTTP methods. Thanks to this, this service is easy to integrate with a variety of tools and libraries, serving the presentation of spatial data. The GetCapabilities operation provides information about the available parameters and resources in a specific WMS service. When the structure of the provided resources is known, access to them is realized by the WMS GetMap request in the form presented below:

http://gis.um.wroc.pl/services/OGC mpzp/MapServer/WMSServer?service=WMS \&ver sion=1.1.0\&request=GetMap\&layers=tereny\&styles=\&bbox=16.7869740000000007,51 $.0320830000000001,17.1958470000000005,51.2199170000000024 \&$ width=1200\&height $=800 \& \operatorname{srs}=\mathrm{EPSG}: 4326 \&$ format=image $/ \mathrm{jpeg}$

In this case, the WMS getMap request is the URI transmitted by the GET method. It is formed by joining the URL service with the list of parameters. The parameters describe the required resources. In addition to general parameters (service, version), the request contains parameters that specify the required object. The most important of these are: layers $=\ldots$, determines the layer / layers that we want to view (in this case layer "zones"), bbox $=\ldots$, defines the spatial extent of the displayed layers, and srs $=$..., spatial reference system, in which spatial extent is defined (e.g., EPSG: 2177). As a result of the request, we get the image presenting layers in the specified extent, which can be displayed in a browser or designated GIS application.

Operation getFeatureInfo is another useful function of the WMS service. Thanks to it, information about a specific object can be obtained. The form of the request (which can also be in the form of the GET method) lets us specify the object that we are interested in. Such indication takes place by specifying the coordinates of the image, which the getMap request can provide us with. Operation getFeatureInfo defines the extent in the same way as getMap, in addition to indicating the pixel location of the specified object. The WMS service, which contains information about the relation between raster image pixel coordinates and the actual position in space, is able to select the element from the data source and give us the associated descriptive information. This information may be in various formats: GML, HTML or plain text, which allows it to be presented in any relevant form (in Fig. 3, this information has been presented in a pop-up window).

The WFS service gives us the possibility to obtain more comprehensive and universal information. It also allows for the entire set of data to be downloaded. The back-end system behind the WFS service determines what data and the extent of it that is available for publishing. Map server uses the WFS service to transform the data to the specified application schema, making it available to the user in 
GML format. The user can then utilize such vector-object data in any way he or she pleases. The range of WFS clients is broad and includes: web applications, such as Geoportal, or desktop GIS applications. Such applications can read and render it on the fly, displaying GML data in the form of maps. Other SDI infrastructure nodes can also be clients of the WFS service. Such an application can transform GML from a given application schema into another one, save retrieved resources in other spatial data formats (SHP, TAB), or transform it into a relational form for storing in relational databases.

The WFS service uses a technique similar to that of the WMS. The request takes the form of a demand in the HTTP protocol, using methods such as the GET. Parameters describing the resource are provided in the URI of the service:

http://gis.um.wroc.pl/services/OGC mpzp/MapServer/WFSServer?SERVICE=WFS\&VER SION=1.0.0\&REQUEST $=$ GetFeature $\&$ TYPE $\bar{N} A M E=O G C$ mpzp $:$ tereny $\& S R S N A M E=E P S G: 2177$.

The WFS service allows the user to select objects that interest him. For example, it is possible to filter objects by attribute values. This allows specific requests to be made of the service, reflecting the information that we would like to obtain from the plan. The answer is a file in GML format, containing interesting spatial objects along with their attributes: (example from the Wrocław GIS portal)

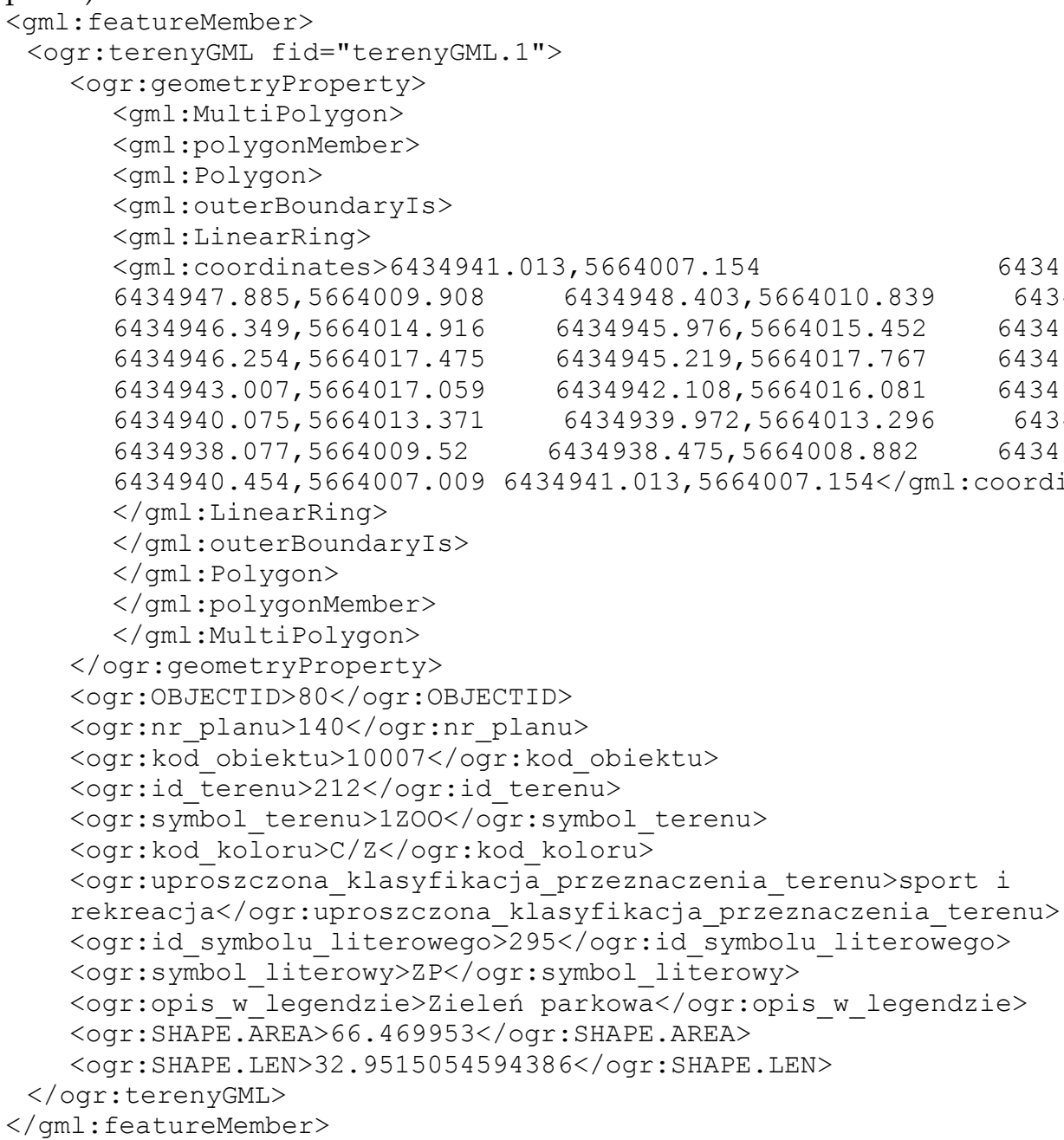

To properly load the spatial planning data into the system, it is necessary to implement mechanisms to import the plan document with the format defined in a XSD file. Most current GIS programs such as ArcGIS, GeoMedia or QGIS can handle the download of data from the WFS, but only containing simple (flat) objects. They are not able to interpret a schema definition document which describes a particular GML structure. They also cannot handle documents with complicated application schemas containing complex objects linked by references to other resources.

The INSPIRE Directive has launched works on the harmonization of data from different databases, which represent different application schemas. The aim is to create the ability to relate them to a common generalized format, defined as an XSD document, specified in the Data Specification. 
Application schema for spatial planning in the form of an XML schema definition (XSD) is developed under the INSPIRE theme of land use.

In accordance with the classification set out in INSPIRE, the WMS service is used only to preview spatial data, whereas WFS is the main service for retrieving and exchanging spatial data in an on-line mode. What is more, every Member State of the European Union must implement a download services for the off-line mode, that is for downloading GML files.

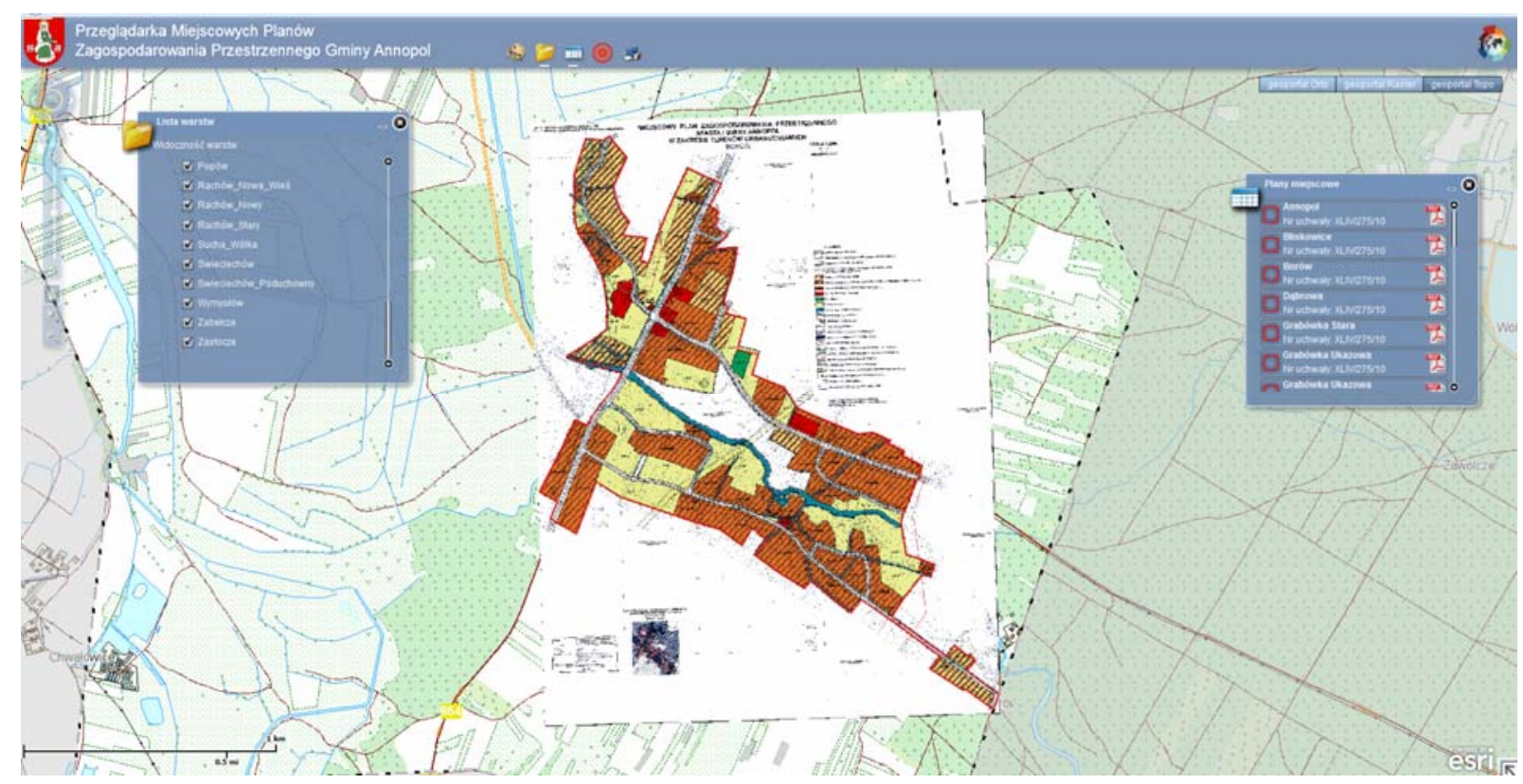

Fig. 1. Georeferenced raster image of the spatial development plan (method 2), Source: http:// portal.gis-expert.pl/lubelszczyzna/annopol/.

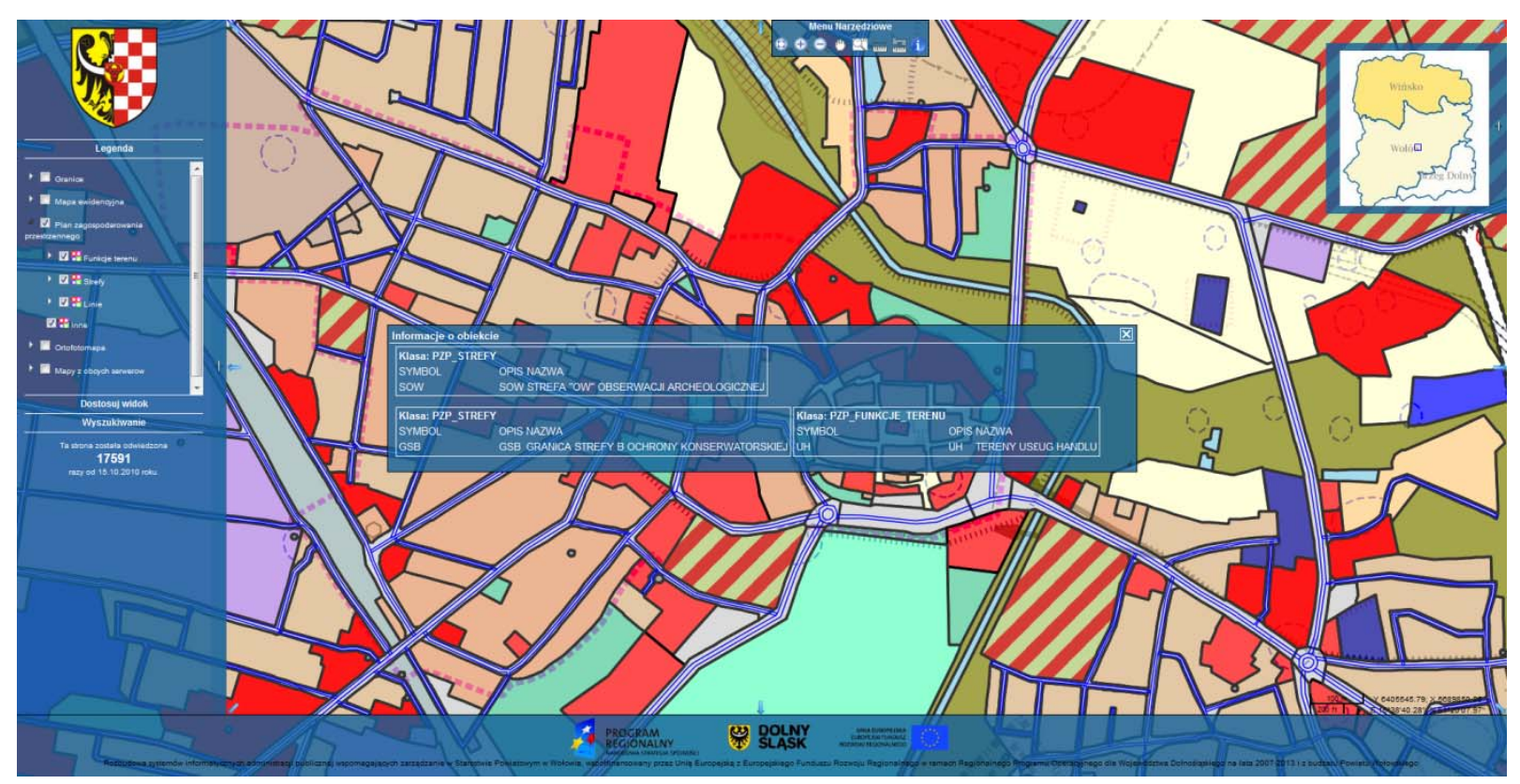

Fig. 2. Vector form of a local plan with information about the given object (method 4), Source: http://geoportal.powiatwolowski.pl/.

The analysis of selected municipality geoportals reveals that the most frequently used geoinformation service for publishing zoning plans in Poland is the WMS, using raster/vector data resources. This is due to the fact that it is easier to implement and maintain. The WMS does not require such a strong network infrastructure and hardware. It also allows the use of limited data 
models to obtain resources which are treated as source data.

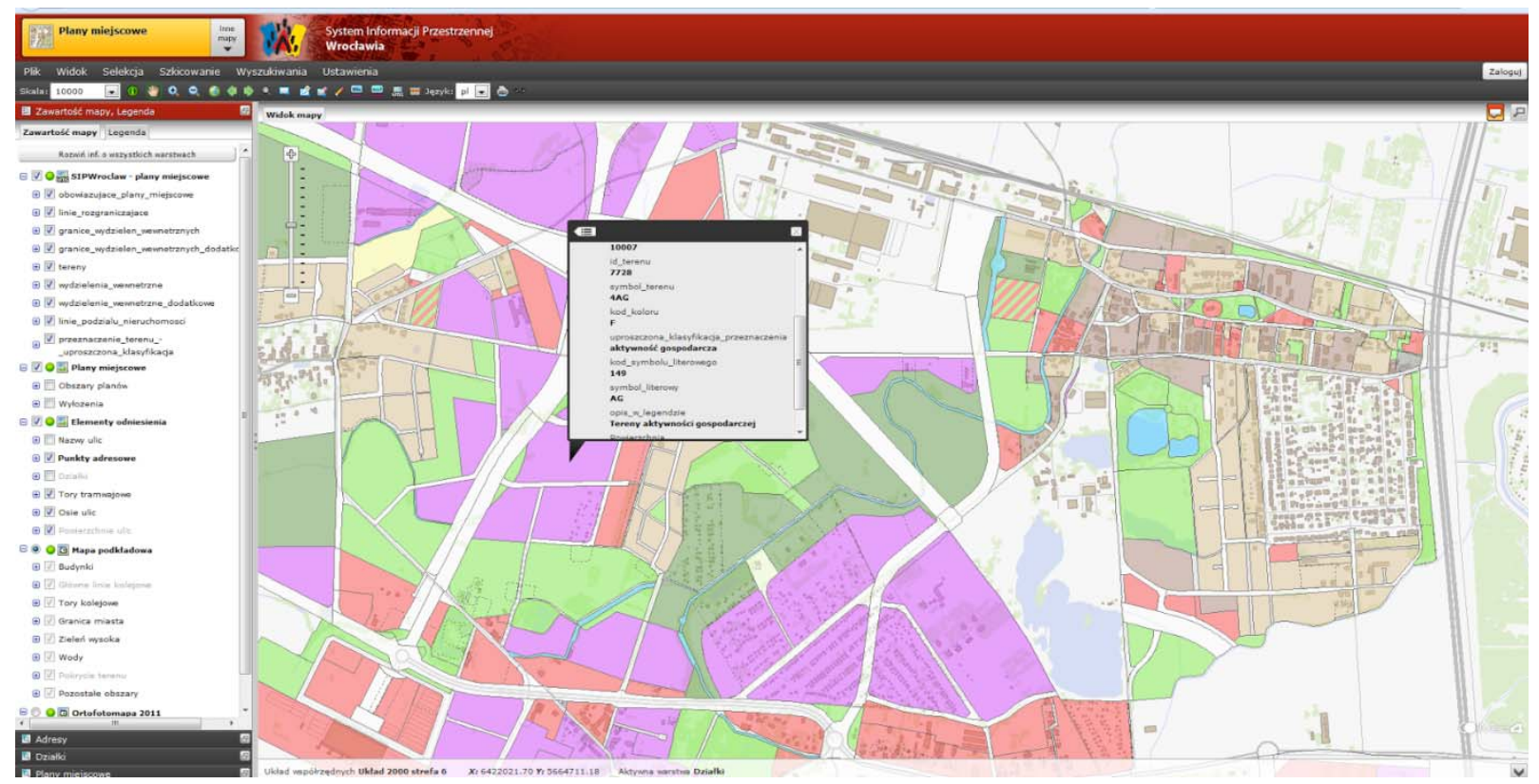

Fig. 3. WMS access of the selected provisions of local development plans along with the getFeaureInfo method (method 6), source: http:/ / www.geoportal.wroclaw.pl.

Table 1 presents the comparison of possible methods of sharing spatial planning data. Several methods and their characteristics have been described.

Table 1

Comparison of methods of sharing spatial planning data along with their characteristics

\begin{tabular}{|c|c|c|c|c|c|c|}
\hline $\begin{array}{l}\text { Method } \\
\text { Characteristics }\end{array}$ & PDF & $\begin{array}{l}\text { CAD - } \\
\text { dxf, } \\
\text { dwg,dgn }\end{array}$ & SHP & GML & KML & $\begin{array}{l}\text { WMS - raster } \\
\text { as input data }\end{array}$ \\
\hline 1 & 2 & 3 & 4 & 5 & 6 & 7 \\
\hline Format of document/data & binary & $\begin{array}{l}\text { dxf - text, } \\
\text { dwg, dgn } \\
\text { - binary }\end{array}$ & $\begin{array}{l}\text { complex } \\
\text { (set of text } \\
\text { and binary } \\
\text { files) }\end{array}$ & XML & XML & JPG, PNG, JPG \\
\hline Data access & off-line & off-line & off-line & off-line & $\begin{array}{l}\text { off-line/ } \\
\text { on-line }\end{array}$ & on-line \\
\hline Data model & none & vector & $\begin{array}{l}\text { simple } \\
\text { object } \\
\text { model in } \\
\text { vector } \\
\text { format }\end{array}$ & $\begin{array}{l}\text { complex } \\
\text { object } \\
\text { model in } \\
\text { vector } \\
\text { format }\end{array}$ & $\begin{array}{l}\text { simple } \\
\text { object } \\
\text { model in } \\
\text { vector } \\
\text { format }\end{array}$ & raster \\
\hline Standard & $\begin{array}{l}\text { ISO } \\
32000\end{array}$ & $\begin{array}{l}\text { lack of, } \\
\text { dxf, de } \\
\text { facto } \\
\text { standard }\end{array}$ & $\begin{array}{l}\text { lack of, } \\
\text { de facto } \\
\text { standard }\end{array}$ & $\begin{array}{l}\text { OGC, ISO } \\
19136\end{array}$ & OGC & OGC, ISO 19128 \\
\hline $\begin{array}{l}\text { Ability to integrate } \\
\text { distributed spatial data } \\
\text { with other resources }\end{array}$ & $\begin{array}{l}\text { very } \\
\text { low }\end{array}$ & low & average & average & average & $\begin{array}{l}\text { generally low, } \\
\text { very high for } \\
\text { composition of } \\
\text { many WMS }\end{array}$ \\
\hline
\end{tabular}




\begin{tabular}{lllllll}
\hline & & & & & & layers \\
\hline Attribute data & none & limited & yes & yes & yes & yes \\
\hline $\begin{array}{l}\text { Popularity of } \\
\text { implementation }\end{array}$ & $\begin{array}{l}\text { very } \\
\text { high }\end{array}$ & $\begin{array}{l}\text { very } \\
\text { high }\end{array}$ & high & average & high & $\begin{array}{l}\text { very } \\
\text { high }\end{array}$ \\
\hline $\begin{array}{l}\text { Availability of the data } \\
\text { model - application } \\
\text { schema }\end{array}$ & none & none & yes & $\begin{array}{l}\text { yes, as } \\
\text { additional } \\
\text { XSD }\end{array}$ & $\begin{array}{l}\text { yes, } \\
\text { predefined } \\
\text { by KML } \\
\text { schema } \\
\text { (XSD) }\end{array}$ & no \\
\hline
\end{tabular}

Table 1 Contd.

\begin{tabular}{|c|c|c|c|c|}
\hline $\begin{array}{l}\text { Method } \\
\text { Characteristics }\end{array}$ & $\begin{array}{l}\text { WMS - vector } \\
\text { as input data }\end{array}$ & WFS & HTML + RDFa & RDF, OWL \\
\hline 7 & 8 & 9 & 10 & 11 \\
\hline $\begin{array}{l}\text { Format of } \\
\text { document/data }\end{array}$ & $\begin{array}{l}\text { JPG, PNG, } \\
\text { JPG, SVG }\end{array}$ & XML (GML) & XHTML, HTML5 & $\begin{array}{l}\text { RDF/XML, RDF } \\
\text { Turtle, N3, } \\
\text { OWL/XML, } \\
\text { Manchester OWL, } \\
\text { OWL Functional } \\
\text { Syntax }\end{array}$ \\
\hline Data access & on-line & on-line & on-line & off-line \\
\hline Data model & $\begin{array}{l}\text { raster/vector; } \\
\text { with access to } \\
\text { the description } \\
\text { of the selected } \\
\text { objects }\end{array}$ & $\begin{array}{l}\text { complex object } \\
\text { model in vector } \\
\text { format }\end{array}$ & $\begin{array}{l}\text { semantic } \\
\text { annotations with } \\
\text { reference to } \\
\text { vocabularies }\end{array}$ & $\begin{array}{l}\text { data as a graph with } \\
\text { references to } \\
\text { ontologies and other } \\
\text { resources }\end{array}$ \\
\hline Standard & $\begin{array}{l}\text { OGC, ISO } \\
19128\end{array}$ & OGC, ISO 19142 & $\begin{array}{l}\text { W3C HTML } \\
\text { RDFa }\end{array}$ & W3C RDF, OWL \\
\hline $\begin{array}{l}\text { Ability to integrate } \\
\text { distributed spatial data } \\
\text { with other resources }\end{array}$ & $\begin{array}{l}\text { generally low, } \\
\text { very high for } \\
\text { composition of } \\
\text { many WMS } \\
\text { layers }\end{array}$ & average & high & very high \\
\hline Attribute data & yes & yes & yes & yes \\
\hline $\begin{array}{l}\text { Popularity of } \\
\text { implementation }\end{array}$ & very high & average & low & very low \\
\hline $\begin{array}{l}\text { Availability of the data } \\
\text { model - application } \\
\text { schema }\end{array}$ & $\begin{array}{l}\text { generally no, } \\
\text { except for } \\
\text { feature info }\end{array}$ & $\begin{array}{l}\text { yes, XSD, } \\
\text { DescribeFeature- } \\
\text { Type method }\end{array}$ & $\begin{array}{l}\text { yes, ontology in } \\
\text { OWL }\end{array}$ & yes, ontology in OWL \\
\hline
\end{tabular}

Source: own study.

\section{Difficulties with publishing spatial planning data}

Difficulties with publishing zoning plans are mainly connected with the problem of developing a consistent standard for plans. Attempts to create a standard for recording or at least publishing plans have been ongoing for many years. Problems include the complex structure of the plans, which 
include information about transport, the infrastructure, social, demographic, economic and environmental issues, etc. Technical difficulties are related to the form of the planning document, which contains both a graphical and textual part. The Spatial Planning and Land Development Act and Regulation of 26 August 2003 on the required scope of the project of the zoning plan, defines the basic types of land use as well as the definitions and regulations which such a plan should contain. However, it is highly insufficient and, in practice, every planner creates his or her own model and using one's own definitions.

The differences in zoning plans apply both to the symbols used in the plan drawings and to the structure of the resolution itself. The standard for plan recording contains guidelines for composing the plan drawing, including standardized graphical elements, as well as for preparing the text regarding the regulations contained within the plan, its structure and definitions of the terms used. The aim of the standardization is, in this case, to allow an unambiguous interpretation of the elements of the plan. The standard for publishing planning documents is meant to solve the problem of plan integration and sharing. While developing a standard for recording plans is a complex task and it is difficult to achieve satisfactory results, developing a standard for publishing plans seems feasible. Implementing the INSPIRE Directive is very helpful in achieving this. Bigger municipalities, such as: Wrocław, Warsaw, Gdańsk, or counties, e.g., Wrocław County, carry out activities aimed at adopting common standards for recording and publishing zoning plans. For instance, the Municipality of Wrocław has standards of spatial planning documents which include unified lists of land use types, symbols, patterns for recording the regulations of a plan and rules for constructing a resolution (J. Brzuchowska, 2010).

The problem of the standardization of spatial planning documents is still a current and often raised issue. The conference "Standardization and spatial planning, current state and future perspectives", organized in 2012 by the Regional Chamber of Town Planners in Katowice and Institute of Urban Development in Cracow, pointed to the difficulties arising, in particular, with the standardization of the textual arrangements of a plan. An essential subject of standardization should include the definitions used in spatial planning. The need to develop a national list of spatial planning concepts was emphasized.

The Plan4all project, the aim of which is the harmonization of spatial planning data according to the INSPIRE Directive, has been initiated at the European level. The project is based on the best practices in various regions and municipalities within the EU, as well as the results of other research projects. The Plan4all Project focuses on the following 7 spatial data themes included in Annex II and III of the INSPIRE Directive: Land cover, Land Use, Utility and Government Services, Production and Industrial Facilities, Agricultural and Aquaculture Facilities, Area Management/Restriction/Regulation Zones and Reporting Units, and Natural Risk Zones. Data models for the selected themes were created as well as a metadata profile and networking service architecture for spatial planning. In order to search for spatial data sets and spatial data services, the Plan4all geoportal was created.

\section{Access to planning information in INSPIRE}

The aim of the INSPIRE (Infrastructure for SPatial InfoRmation in Europe) Directive, which came into power in May 2007, is to develop the Spatial Data Infrastructure in Europe. The Directive was implemented in Polish national law in 2010 in the form of the Act of March 42010 on Spatial Information Infrastructure. The main assumption for building a spatial information infrastructure is to allow for public access to spatial data so that environmental protection policies can be supported. According to the Directive, the elements of a spatial information infrastructure are:

- metadata,

- spatial data sets,

- spatial data services,

- web services and technologies,

- agreements on mutual data access and usage,

- mechanisms, processes and procedures for control and monitoring.

An attachment to the Act of March 42010 on Spatial Information Infrastructure contains 34 themes divided into 3 groups which define the problems and scope of the data covered by the infrastructure. One of them is the topic of "land use", understood as "territory characterized according to its current 
and future planned functional dimension or socio-economic purpose (e.g., residential, industrial, commercial, agricultural, forestry, recreational), which is the result of the planning documents."

Developing the spatial data infrastructure affects spatial planning in two ways. On the one hand, it gives town planners a new source of up-to-date, structured and verified spatial data, which considerably facilitates their work. This primarily applies to reference data, i.e., administrative units, buildings, parcels, addresses, hydrography, transport, etc. On the other hand, it brings about a new quality to publishing the results of the products of spatial planning, including zoning plans, giving the interested institutions and citizens a rich source of information about future land development. Spatial planning is, thus, not only a beneficiary of the infrastructure, but also a data provider.

In the context of tasks related to spatial planning, the INSPIRE project defines the following tasks:

- standardizing information concerning existent and future land use by creating a data model according to D2.8.III.4 Data Specification on Land Use - Draft Technical Guidelines (the specification has not been adopted yet),

- creating metadata for spatial planning documents,

- ensuring technical, organizational and semantic interoperability in terms of the data and services related to the field of spatial development.

According to the Act on the Spatial Information Infrastructure, the Polish Ministry of Transport, Construction and Maritime Economy is the institution responsible for the topic of "land use" and is obliged to coordinate all work related to creating metadata for planning documents. To fulfill the duties imposed by INSPIRE, all member countries are obliged to develop metadata for the subject of "land use" before December 3rd 2013. The zoning plan has been chosen as the spatial data set to be described by the metadata. It is worth noting that the obligation to publish data in the spatial information infrastructure applies only to electronically stored data. In cases when municipality authorities possess an analogue version of the plans, implementing the INSPIRE Directive is a good incentive to digitize the planning resources.

It is also worth noting that work done on the subject of "land use" should lead to developing a consistent model for the exchange of spatial planning data. The guidelines related to publishing data in this model can be found in the already mentioned D2.8.III.4 technical document. The structure of the data model which is included in the specification places zoning plans in the planned land use (PLU) category. The application schema of the model is based on three main classes:

1) SpatialPlan - defines the plan as a type of spatial object. It has to be described using such attributes as: object identifier, scope (area), title, document hierarchy level, etc.,

2) ZoningElement - defines a spatial object which has obligatory attributes such as: an object identifier, geometry, value of the Hierarchical INSPIRE Land Use Classification System (HILUCS), legal status,

3) SupplementaryRegularion - defines a type of object which contains additional regulations and agreements which may be imposed on a given area, e.g., noise zones, air pollution zones.

The deadline for works on the spatial data set in the subject of land use is 2015 for data sets which were created after the appropriate regulations had come into power. The year 2019 is the final deadline for the rest of the data sets.

There is no doubt that adjusting planning information to the postulates of the INSPIRE Directive requires considerable effort and costs. The responsible institutions have to build an information infrastructure (spatial information nodes which share resources using web map services), adjust the shared documents to the required standards and describe them using metadata which is to be published in catalogue services. However, the potential benefits of implementing the INSPIRE Directive are worth the considerable time and financial effort.

Firstly, with the implementation of this Directive we acquire consistent spatial development information in the scope of Poland and Europe. Its integration with the Land and Property Register as well as environmental data, i.e., soil, air and water quality, or the occurrence of various forms of environment protection, will allow for spatial development to be treated comprehensively as well as for the system-level shaping of space and organization of investments. It will be useful for officials making strategic decisions as well as for investors trying to find appropriate real estate for investment or ordinary citizens interested in what is happening around them. Additionally, by facilitating access to spatial planning data, one can expect an increase in the level of public participation, which is very low at the moment. 


\section{Future trends in access to spatial planning data}

INSPIRE makes it possible to publish zoning plans in a way which allows for their analysis, processing and extensive use. The implementation of the Directive means the beginning of the end of the analogue era in Poland. The changing situation depends not on the increasing awareness of changes but on the obligation to respect European law which necessitates specific actions. The experiences of countries such as Germany and the Netherlands prove that developing standards for spatial planning is possible on a national level. It is worth noting that the work done in these countries is the result of the bottom-up approach, based on the actions of subjects interested in this matter. It is not the result of any necessity to fulfill European requirements, but rather the awareness of better and more effective space management. The top-down approach remains dominant in Poland, which results from the fact that actions leading to standardization are performed by central state authorities and are necessary in order to implement the Directive.

Information technology development, which allows for internet resources to be published and integrated on a wider scale, is done in parallel to efforts taken to implement INSPIRE and introduce standards. Solutions using semantic web technologies, which have been created in the rapidly developing Semantic Web project, are mainly based on building ontologies. Ontologies are a formal representation of a given area of knowledge but, unlike object-oriented models found in the INSPIRE specification, they are formed on the basis of descriptive logic. Currently, research covering both efforts to record spatial development plans using the ontology modeling language OWL (KACZMAREK et al. 2011) as well as to create semantic metadata for the plans is being undertaken. The other assumption is to use a standard of describing Internet resources such as RDFa, which gives greater possibilities in terms of browsing and integrating information contained in planning documents than developing INSPIRE metadata. RDFa seems to be a convenient tool for publishing spatial planning information. It allows traditional HTML documents to be enriched with machine-readable content without losing the possibility of reading them in commonly used browsers. It could be said that all existing Web technology (including Web 2.0) retains its usefulness.

RDFa provides a number of attributes supporting traditional HTML attributes. They allow for objects to be defined according to classification stored in the domain glossary, e.g., spatial planning. Such vocabulary, written in RDF or OWL language, is called TBox - terminological component. HTML tags indicate which parts of the text are associated with these objects. RDFa attributes provide for the identification of unique resources by the given URI and allow for their class to be determined. The natural language text description of the objects in the document includes a reference to RDFa properties. The text includes the literal (textual and numerical) values of properties, as well as references to other objects. Such fragments, annotated by RDFa attributes within HTML attributes, correspond to properties defined in the vocabulary. Beyond the semantic information, which is machine-readable (for crawlers, agents, spiders), RDFa can provide a layer of Linked Data, as it provides reference to external resources. For example, it can define the relations between the spatial planning objects presented in document and objects accessible in the cadastre, address database or resources available on the WWW, e.g., in the DBpedia as well as GeoNames services.

There are various methods of implementing annotations in HTML documents. RDFa annotations can be performed at different stages of creating and sharing documents. Firstly, a planning document can be created from scratch. For this purpose, dedicated editors are provided, allowing for the spatial plan act to be written "semantically". The designer of the zoning plan, when creating the text of a plan in natural language, will simultaneously define appropriate objects and their properties, using the provided glossary. The second option is to annotate existing documents, available in repositories such as legal registers. In this case, the document will be imported from the source and supplemented with the attributes of RDFa within HTML tags. The last option is to generate these documents from databases containing spatial objects, which have references to the regulations in the plan. Descriptive data from the database will be combined with text in natural language, which is a content of the legal act using templates and reflecting the structure of the document.

The idea of using the technology of a semantic web in the field of spatial planning is being developed also in order to build tools aiding administrative and management decisions (IWANIAK 2012), (IWANIAK, 2013). In these works, the authors presented the concept of a system which integrates spatial data as well as information and knowledge regarding space. The proposed approach is aimed at developing an intelligent spatial development decision supporting system. Other research concerns 
using semantic structures for organizing information, which plays an important role in the sharing of planning data as well as its standardization. Their aim is not only to organize knowledge in the field of spatial planning but also to facilitate searching for planning documents in catalogue services (KACZMAREK, 2011). It is to be expected that the growing interest in employing semantic web technologies in the areas of GIS and SDI will express itself in the field of spatial planning.

\section{Conclusion}

According to the currently dominant views (ŹRÓBEK 2010), real property management may be treated as a system which is both the "consumer" and the "producer" of spatial information. An accurate description of reality is insufficient for the effective management of real property. All states and relations occurring within a system as well as between other systems, especially spatial development plans, have to be taken into account. In addition to being a formal base for investment, zoning plans are a source of information about the currently planned and possible uses of the property in question. Current information technologies based on web solutions provide advanced methods for processing spatial information. The information provided by plans, regardless of its degree of specificity, represents one of the most important sources of information for potential uses of the spatial information infrastructure and thus, professional groups related to real estate management.

The process of identifying the actions needed in terms of standardizing spatial planning, initiated by the Directive, is promising. Most public administration units responsible for creating spatial plans do not take sufficient action to improve the current situation and initiative is taken by what is widely understood as the geoinformation business. However, a concern that the process of improving the spatial planning system will not meet expectations persists. A lack of financial resources may limit the scope of actions taken at the national level to only those allowing for the minimum requirements of the INSPIRE Directive to be fulfilled.

In parallel to European activities concerning the sharing of planning documents, new solutions, which provide previously unavailable possibilitie,s are appearing. This brings hope for a broader use of the distributed and heterogeneous information found in zoning plans without giving up the attempts taken at standardization.

\section{References}

BRZUCHOWSKA J., 2010, Wykorzystanie planów zagospodarowania przestrzennego w Systemie Informacji Przestrzennej Wrocławia. Wykorzystanie Systemu Informacji Przestrzennej w planowaniu zagospodarowania przestrzennego Wrocławia, Conference materials, "Publiczny dostęp do informacji o zagospodarowaniu przestrzennym - od szczebla lokalnego do europejskiego", Katowice.

IWANIAK A., ŁUKOWICZ J., STRZELECKI M., KACZMAREK I., 2012, Implementacja inteligentnej infrastruktury informacji przestrzennej, Roczniki Geomatyki, Vol. X No. 4 (54), pp. 119-132, Warszawa.

KACZMAREK I., IWANIAK A., 2011, Rola tezaurusa w budowie interoperacyjności semantycznej, Roczniki Geomatyki, Vol. IX No. 4 (48), pp. 61-69, Warszawa.

KaczmareK I., Łukowicz J., CoOPer A., IWANiAK A., KubiK T., PALuszynski W., 2011, The use of ontologies in the spatial planning domain, 25th International Cartographic Conference, Paris, 4-8 July 2011, pp. CO-089.

KACZMAREK I., IWANIAK A., Publication of spatial planning documents using ontology-driven approach, 2013, Conference INSPIRE Green Renaissance, Florence, http://inspire.jrc.ec.europa.eu/events/conferences/inspire_2013/schedule/submissions/256.html, accessed 14.06.2013.

IWANIAK A., ŁUKOWICZ J., KACZMAREK I., STRZELECKI M., The use of semantic web technologies in Spatial Decision Support Systems, 2013, Conference INSPIRE 2013:The Green Renaissance, Florence, http://inspire.jrc.ec.europa.eu/events/conferences/inspire_2013/schedule/submissions/264.html, accessed 14.06.2013.

SZWAJDLER T., BĄKOWSKI T., 2004, Proces inwestycyjno-budowlany. Zagadnienia administracyjno-prawne, TORUŃ.

ŚMIETANA K., ZAGÓRSKA E., 2012, Bariery informacyjne w działalności zawodowej zarządcy nieruchomości. Studia i Materiały Towarzystwa Naukowego Nieruchomości.

ŹRÓBEK R., 2010, Zasady gospodarki nieruchomościami zgodnie z uwzględnieniem jej podstaw informacyjnych, Studia i Materiały Towarzystwa Naukowego Nieruchomości. 
WoźNiaK E., IWANIAK A., NetZel P., Wykorzystanie standardów OGC do wizualizacji danych w infrastrukturze informacji przestrzennej, Cz. 2, Przegląd Geodezyjny 83 (5), pp.12-17.

Act of March 42010 on spatial information infrastructure (Journal of Laws No. 76, item 48).

Directive 2007/2/EC of the European Parliament and of the Council of 14 March 2007 establishing an Infrastructure for Spatial Information in the European Community (INSPIRE).

D2.8.III.4 Data Specification on Land use - Draft Technical Guidelines, 2013, INSPIRE Data Specification for the spatial data theme Land use, INSPIRE Thematic Working Group Land use

Plan4all, http://wwww.plan4all.eu/, accessed 14.06.2013.

Plan4all D3.2.2, 2010, Plan4all Metadata Profile -Final version, http://www.plan4all.eu/extractor/fileReader.php?file $=d 3-2-2$-plan4all-metadata-profile-final-versionrevised.pdf, accessed 14.06.2013.

Plan4all D4.2, 2010, Conceptual Data Models for Selected Themes, http://www.plan4all.eu/extractor/fileReader.php?file=d4-2-conceptual-data-models-for-selected-themes.pdf, accessed 14.06.2013.

Plan4all D 5.2, 2010, Plan4all Networking Architecture, http://www.plan4all.eu/extractor/fileReader.php?file $=d 5-2$-plan4all-networking-architecture.pdf, accessed 14.06.2013.

Regulation of 26 August 2003 on the required scope of the project of zoning plan (Journal of Laws No. 164, item 1587).

Spatial Planning and Land Development Act of 27 March 2003 (Journal of Laws No. 80, item 717). 